\title{
PERANAN BADAN WAKAF INDONESIA DALAM PENYELESAIAN SENGKETA TANAH WAKAF
}

\author{
Mohammad Syamsul Arifin \\ Program Studi Magister Kenotariatan PPS Unisma \\ Jalan Mayjen Haryono Nomor 193 Malang \\ Email: arifin2015.@gmail.com
}

\begin{abstract}
Abstrak
Di dalam agama Islam wakaf merupakan ibadah yang bernuansa penuh dengan rasa cinta kasih terhadap sesama manusia, menyejahterakan kepentingan orang lain bahkan kepentingan umum, dengan mewakafkan harta benda maka, akan tercipta solidaritas seseorang terhadap sesamanya. Akan tetapi di lapangan sering terjadi sengketa yang didahului oleh unsur kepentingan. Dalam penyelesain sengketa menggunakan metode penyelesain sengketa di luar pengadilan atau non litigasi yaitu menggunakan metode mediasi yang di lakukan oleh nadzir dan waqif dalam penyelesaian masalah. Adapun faktor dari sengketa khusus Masjid Tawakkal adalah unsur kepentingan baik oleh wakif maupun nadzir sedangkan peranan Badan Wakaf Indonesia dalam penyelesaian sengketa wakaf adalah berpedoman pada pasal 62 ayat 1 dan 2 Undang-undang Nomer 41 tahun 2004 yaitu BWI dalam penyelesaian sengketa wakaf mengedepankan musyawarah mufakat.
\end{abstract}

Kata kunci: penyelesain sengketa, wakaf, nadzir dan wakif

\section{Abstract}

In Islam, waqf is nuanced worship full of love for fellow human beings, welfare of the interests of others and even public interests, by endowing property, there will be a solidarity between one another. However, in the field there are often disputes which are preceded by elements of interest. In resolving disputes using the method of resolving disputes outside the court or non-litigation, namely using the mediation method that is done by Nadzir and Waqif in solving problems. The factors of special dispute Tawakkal Mosque are elements of interest both by wakif and nadzir while the role of the Indonesian Waqf Agency in settlement of waqf disputes is guided by article 62 paragraph 1 and 2 of Law Number 41 of 2004 namely BWI in resolving endowments disputes prioritizing consensus. Keywords: dispute resolution, waqf, nadzir and wakif 


\section{PENDAHULUAN}

Di dalam Agama Islam wakaf merupakan ibadahyang bernuansa penuh dengan rasa cinta kasih terhadap sesama manusia, menyejahterakan kepentingan orang lain bahkan kepentingan umum, dengan mewakafkan harta benda maka, akan tercipta solidaritas seseorang terhadap sesamanya.

Wakaf berasal dari kata waqafa (menahan, berhenti, diam di tempat, tetap berdiri). Kata ini sama artinya dengan habasa. Adapun menurut syara' wakaf adalah menahan dzat (asal) benda dan mempergunakan hasilnya, artinya menahan benda dan mempergunakan manfaatnya di jalan Allah. ${ }^{1}$

Wakaf juga diatur dalam Undang-undangNomor 5 Tahun 1960 mencantumkan adanya suatu ketentuan khusus sebagaimana terdapat dalam Pasal 49 Ayat (3) yang berbunyi: perwakafan tanah milik dilindungi dan diatur dengan peraturan pemerintah.Pada umumnya umat Islam Indonesia memahami bahwa peruntukan wakaf hanya terbatas untuk kepentingan peribadatan dan hal-hal yang lazim dilaksanakan di Indonesia seperti untuk masjid, musholla, sekolah, makam dan lain sebagainya. Sehingga dapat dikatakan bahwa di Indonesia saat ini potensi wakaf sebagai sarana berbuat kebijakan bagi kepentingan masyarakat belum dikelola dan diberdayagunakan secara maksimal dalam lingkup perekonomian nasional.

Dalam lingkungan masyarakat kita, tercipta suatu gambaran serta persepsi tertentu mengenai wakaf. Pertama, wakaf itu umumnya berwujud benda tidak bergerak khususnya tanah, padahal dalam wakaf tidak terbatas pada benda yang tidak bergerak saja akan tetapi wakaf bisa benda yang bergerak. Kedua dalam kenyataan diatas tanah itu didirikan bangunan atau madrasah, kenyatannya tidak semua tanah wakaf harus di bangun tempat ibadah atau madrasah akan tetapi bisa bentuk yang lain misalnya pos kamling dan lain sebagainya, asal di buat kebaikan dan mempunyai nilai manfaat. Ketiga penggunaannya didasarkan pada wasiat pemberi wakaf (wakif) padahal wakaf tidak harus berupa wasiat yang harus dilaksanakan oleh wakif akan tetapi bisa diberikan sendiri oleh yang mempunyai hak. Dalam pengelolaan harta wakaf produktif, pihak yang paling berperan berhasil atau tidaknya pemanfaatan harta wakaf adalah nadzir, yaitu seorang atau sekelompok orang dan badan hukum yang diserahi tugas oleh wakif (orang yang mewakafkan harta) untuk mengelola wakaf. Akan tetapi tidak menutup kemungkinan jika telah produktifnya tanah wakaf menimbulkan persengketaan antara para nadzir tersebut, hal ini banyak terjadi dilingkungan masyarakat kita terhadap nadzir yang tidak bertanggung jawab dan hanya berfikir kearah menciptakan keuntungan sendiri saja, sehingga mengesampingkan kemaslahatan umat.

${ }^{1}$ Sayid Sabiq, Fiqh al Sunnah, Jilid 3.(Beirut: Dar al Fikr, 1983), hal. 378. 
Contoh konkrit yang terjadi pada tanah dan rumah yang ada di Kota Malang yang terletak di Jalan Bantaran Gg, 4 Nomor. 14 RT.01 RW.03 Kelurahan Tulusrejo Kecamatan Lowokwaru Kota Malang. Tanah tersebut diwakafkan oleh suami istri (Bapak H Asnan Ghozali dan Ibu Hj Siti Arina) kepada H Masrur Yasir untuk selanjutnya diberi amanat oleh suami istri tersebut sebagai nadzir wakaf, yang kemudian diatas tanah dan rumah yang ada di atasnya wakaf tersebut, yang pertama rumah yang dipergunakan untuk sarana ibadah, karena perkembangan jaman, dan sesuai dengan keputusan musyawarah keluarga ingin mewakafkan sebagian tanahnya buat tempat ibadah, maka yang semula berupa rumah tersebut di bongkar dan di bangun yang lebih besar menjadi masjid yang keinginan awalnya di biayai oleh keluarga akan tetapi ada sumbangan dari kaum muslimin dan muslimat yang ingin menyumbang maka di beri ruang, akhirnya di beri nama Masjid Tawakkal, yang selain dipergunakan sebagai sarana ibadah, bangunan masjid tersebut dipergunakan juga untuk sarana pendidikan yang bernuansa Islam yang berupa Taman Pendidikan Al-Qur'an TPA), seiring berjalannya waktu dan berkembangnya sarana pendidikan tersebut yang pada akhirnya dirasa memiliki nilai manfaat bila diukur secara ekonomi. Timbulah sengketa antar nadzir tanah wakaf tersebut, yaitu pihak yang bersengketa sama-sama terlihat ingin memiliki dan menguasai manfaat dari tanah wakaf tersebut yaitu ahli waris dari almarhum Bapak $\mathrm{H}$ Asnan Ghozali dan Ibu $\mathrm{Hj}$ Siti Arina. Yang pada akhirnya berujung pada ikrar wakaf yang secara autentik yang utama sampai terbengkalai.

Berdasarkan uraian tersebut diatas, maka penulis bermaksud untuk menulis hal yang berkenaan dengan wakaf serta permasalahan yang terdapat didalamnya, adapun permasalahan tersebut adalah mengapa Terjadi sengketa antara Nadzir tanah wakaf dengan ahli waris wakif dan bagaimanakah penyelesaian masalah jika terjadi sengketa antara nadzir tanah wakaf dengan ahli waris wakif, serta bagaimanakah peranan Badan Wakaf Indonesia (BWI) dalam menyelesaikan sengketa tersebut

\section{METODE PENELITIAN}

Penelitian adalah salah satu bentuk komonikasi antara ilmuan. Cara melakukan komonikasi ilmiah yang baik dan cermat tidak akan dapat dikuasai secara tiba-tiba, diperlukan latihan secara sistematis disertai penguasaan ilmu yang tepat. ${ }^{2}$ Dalam penelitian ini jenis yang digunakan adalah yuridis empiris, Metode penelitian empiris adalah suatu metode penelitian hukum yang berfungsi untuk dapat melihat hukum dalam artian nyata serta meneliti bagaimana bekerjanya hukum dalam suatu masyarakat

${ }^{2}$ Sukandarrumidi, Metodologi Penelitian: Petunjuk Praktis untuk Peneliti Pemula, (Yogyakarta: Gajah Mada University Press,2006), hal. 26-30. 
yang dapat juga dikatakan metode penelitian hukum sosiologis. ${ }^{3}$ Pendekatan yuridis sosiologis adalah mengidentifikasi dan mengkonsepsikan hukum sebagai institusi sosial yang sosiologis dan fungsional dalam sistem kehidupan nyata. ${ }^{4}$

\section{PEMBAHASAN}

\section{Faktor-Faktor Terjadinya Sengketa Antara Nadzir Tanah Wakaf Dengan Ahli Waris Wakif Di Masjid Tawakkal}

Istilah "Sengketa" (Disputes, bahasa Inggris), seringkali disebut sama dengan"konflik" (Conflict, bahasa Inggris). Henry Campbell Black menjelaskan arti "dispute" sebagai "a conflict of controversy; aconflict of claims or rights; an assentationof a right, claim, or demand on one side, met by contrary claims or allegations on theother. The subject of litigation; the matterfor which a suit is brought and upon whichissue is joined, and in relation to whichjurors are called and witnesses examined". 5

Terjadinya konflik kebanyakan di mulai dengan satu perselisihan atau gesekan pendapat atau beda paham dalam bermasyarakat. Dalam teori konflik adalah istilah dalam Bahasa Inggris "conflict theory" yang bermula dari pertentangan kelas sosial antara kelompok masyarakat, kelompok ini terdiri dari kelompok tertindas dan kelompok penguasa sehingga akan mengarah pada bentuk perubahan sosial, baik yang mengarah pada dampak positif perubahan sosial ataupun yang mengarah pada dampak negatif perubahan sosial.

Kalau kita analisis dari teori konflik, maka konflik yang terjadi di masjid Tawakkal, berawal dari penguasaan masjid yang dikuasai oleh masyarakat atau kelas masyarakat yang notabene adalah masyarakat Nahdatul Ulama', akan tetapi keinginan dari ahli waris menginginkan untuk ke yayasan Muhammadiyah. Dari hasil penelitian penyebab atau faktor terjadinya sengketa antara nadzir wakif penulis dapat menyimpulkan sebagai berikut:

1. Tanah wakaf yang diserahkan kepada nadzir tidak di segerakan membuat ikrar wakafnya. (padahal waktu itu masih dalam keadaan masih sehat semuanya)

2. Ikrar dari wakif hanya diberikandengan pernyataan biasa.

\footnotetext{
${ }^{3}$ Nisayustia1. Blogspot.com Di Unduh Pada Hari Senin Tanggal 25 Februari 2019 pukul 01,00 Wib.

${ }^{4}$ Soerjono Soekanto, Pengantar Penelitian Hukum, (Jakarta: Universitas Indonesia Press, 1986), hal.51.

${ }^{5}$ Henry Campbell Black, Black's Law Dictionary, (St. Paul: West Publishing Co., 1989), hal. 424.
} 
3. Masjid Tawakkal berkembang dan dapat menghasilkan secara ekonomi.

4. Sebelum ibu Hj Siti Arina meninggal belum pernah ada ikrar wakaf secara tertulis sampai dengan kepemerintahan.

5. H Masrur Yasir yang tunjuk oleh keluarga sebagai nadzir meninggal dunia sebelum adanya ikrar wakaf secara autentik dan bapak Masrur sebelum meninggal menyerahkan kembali kepada ahli waris.

6. Pihak keluarga ingin menyerahkan wakaf tersebut kepada Yayasan Mujahidin.

7. Mendapat penolakan dari masyarakat dan tokoh tokoh masyarakat yang menginginkan wakaf tersebut diberikan kepada kaum Nahdatul Ulama'.

Dari penyebab atau faktor terjadinya sengketa antara nadzir dengan wakif kalau kita analisis dari teori kepastian hukum maka dapat ditarik suatu kesimpulan bahwa belum ada kepastian hukumnya karena salah satu faktornya adalah ketidak adaannya akta ikrar wakaf yang dicatatkan ke badan pembuat akta ikrar wakaf sehinggan secara hukum Masjidtersebut, masih status hak milik pribadi.

\section{Bentuk-Bentuk Penyelesaian Masalah Jika Terjadi Sengketa Antara Nadzir Tanah Wakaf Dengan Ahli Waris Wakif}

Dalam hal penyelesaian sengketa atas tanah wakaf dan sengketa tentang wakaf pada umumnya hal ini diatur dalam Undang-undang Republik IndonesiaNomor 41 Tahun 2004 Tentang Wakaf Pasal 62 menegaskan bahwa penyelesaian sengketa perwakafan ditempuh melalui musyawarah untuk mufakat. Apabila penyelesaian sengketa melalui musyawarah tidak berhasil, sengketa dapat diselesaikan melalui mediasi, arbitrase, atau pengadilan.

Ada dua cara atau bentuk penyelesaian sengketa tanah wakaf yaitu: 1) Jalur pengadilan (legitasi) dan 2) Jalur di luar pengadilan (non ligitasi). Dari dua cara atau bentuk penyelesaian sengketa tanah wakaf terdapat perbedaan mendasar antarabentuk penyelesaian sengketa melaluipengadilan dan penyelesaian sengketa diluar pengadilan. Perbedaan tersebut adalah :

1. Pertama, kedua bentuk penyelesaian sengketa baik melului pengadilan maupun di luar pengadilan, merupakan aturan hukum(regelen recht). Yang berbeda, ialah tidaksemua aturan hukum berisikan hukumsanksi (santie-recht).

2. Penyelesaiansengketa melalui pengadilan memiliki sanksi hukum yang bersifat otonom, sedangkan penyelesaian sengketa di luar pengadilan, sanksinya bersifat heteronom.Dikatakan bersifat otonom, oleh karena upaya paksa jika putusan pengadilan tidak dilaksanakan oleh para pihak, ada pada lembaga peradilanantara lainnya melalui aparat 
penegak hukum, lembaga pemasyarakatan, dan lain-lainnya.

Penyelesaian sengketa di luar pengadilan bersifat heteronom dalam penegakan hukumnya, oleh karena putusan arbitrase maupun putusan alternatif penyelesaian sengketa membutuhkan penguatannya lebih lanjut melalui lembaga peradilan. Ada pihak lain yang turut menguatkan kekuatan hukum memaksa dari putusan arbitrase dan alternatif penyelesaian sengketa.

Penyelesaian sengketa yang telah dikenal sejak lama adalah penyelesaian di pengadilan. Akan tetapi proses penyelesaian sengketa, di pengadilan cenderung menimbulkan permasalahan yang baru karena hasilnya adalah bahwa akan ada pihak yangmenang dan kalah dalam pengadilan. Penyelesaian perkaranya juga memakan banyak waktu karena proses peradilan dianggap terlalu berbelit-belit dan penyelesaian perkara melalui pengadilan terbuka untuk umum.

Penyelesaian sengketa di luar pengadilan mulai berkembang seiring perkembangan zaman, dimana penyelesaian sengketa di luar pengadilan bersifat tertutup sehingga dapatdijamin kerahasiaannya dan prosesnya pun lebih cepat. Litigasi (pengadilan) adalah metode penyelesaian sengketa paling lama dan lazim digunakan dalam menyelesaikan sengketa, baik sengketa yang bersifat publik maupun yang bersifat privat.

Seiring dengan berjalannya waktu dan perkembangan zaman, di mana kebutuhan masyarakat akan keadilan dan kesejahteraan semakin besar, maka penyelesaian sengketa melalui litigasi lambat laun dirasakan kurang efektif lagi.Penyelesaian sengketa melalui litigasi dirasakan terlalu lama dan memakan biaya yang cukup besar. Kondisi demikian menyebabkan pencari keadilan mencari alternatif penyelesaian sengketa (APS) atau dikenal juga dengan istilah Pilihan Penyelesaian Sengketa atau dalam istilah asing ADR (Alternative Dispute Resolution) Penyelesaian dengan cara ini harus didasarkan asas itikad baik oleh para pihak yang dimana maksudnya adalah benar-benar ada keinginan para pihak untuk menyelesaikannya dengan cara ini tanpa perlu masuk ke ranah pengadilan. APS dinilai sebagai solusi atau jalan keluar atas kekurangan pengadilan dalam menyelesaikan perkara.

Pengertian Alternatif penyelesaian sengketa dapat kita lihat dalam produk hukum yaitu Undang-undang Republik IndonesiaNomaor 30 Tahun1999 tentang Arbitrase dan Alternatif penyelesaian sengketa dimana dijelaskan dalam Pasal 1 angka 10 yaitu: alternatif penyelesaian sengketa adalah lembaga penyelesaian sengketaatau beda pendapat melaui prosedur yang disepakati oleh para pihak, yaknipenyelesian di luar pengadilan dengan cara konsultasi, negosiasi, mediasi,konsiliasi, atau penilaian ahli. 
Alternatif Penyelesaian Sengketa ini sangatlah sesuai dengan masyarakat Indonesia untuk diterapkan karena APS ini mempunyai asasasas yaitu antara lain:

1. Asas Itikad Baik

Adalah para pihak benar-benar ingin menyelesaikan sengketa dengan ini dengan cara terbuka antara para pihak.

2. Asas Pacta Sunt Servanda

Adalah perjanjian itu mengikat bagi para pihak.

3. Asas Kerahasiaan

adalah segala sesuatu yang terjadi antara mereka dijamin kerahasiaannya tanpa diketahui oleh umum sehingga berbanding terbalik dengan litigasi di Pengadilan yang dimana penyelesaiannya terbuka untuk umum kecuali hal-hal yang ditentukan oleh hukum.

4. Asas Kebebasan Berkontrak.

Adalah penyelesaiannya dilakukan dengan cara mufakat dimana para pihak bebas menentukan cara bagaimana yangakan dilakukan untuk mendapatkan hasil yang sesuai dan memuaskan bagipara pihak.

5. Asas Final and Binding .

Adalah hasil dari APS ini merupakan putusan terakhir dan mengikat para pihak.

Keputusan yang dihasilkan mempunyai kekuatan yang sama dengan keputusan pengadilan yang berkekuatan hukum tetap (inkracht van gewijsde). Dalam Alternatif Penyelesaian Sengketa ini tidak mengenal banding ataupun kasasi sebagaimana dalam proses litigasi di Pengadilan. Selain daripada budaya APS yang memang sudah melekat dalam masyarakat Indonesia, APS juga mempunyai potensi yang besar untuk berkembang di Indonesia karena alasan-alasan sebagai berikut: ${ }^{6}$

1. Faktor ekonomis,

APS memiliki potensi sebagai sarana penyelesaian sengketa yang lebih ekonomis, baik dari sudut pandang biaya maupun waktu.

2. Faktor ruang lingkup yang dibahas,

APS memiliki kemampuan untuk membahas agenda permasalahan secara lebih luas, komprehensif, danfleksibel.

Hal ini dapat terjadi karena aturan main dikembangkan dan ditentukan oleh para pihak yang bersengketa sesuai dengan kepentingan dan kebutuhannya. APS memiliki potensi untuk menyelesaikan konflikkonflik yang sangat rumit (polycentris) yang disebabkan oleh substansi kasus yang sarat dengan persoalan-persoalan ilmiah (scientifically complicated).

${ }^{6}$ Frans Hendra Winarta, Hukum Penyelesaian Sengketa Arbitrase Nasional IndonesiaDan Internasional, (Jakarta, Sinar Grafika. 2011), hal 11-12. 
3. Faktor pembinaan hubungan baik

APS yang mengandalkan cara-cara penyelesaian kooperatif sangat cocok bagi mereka yang menekankan pentingnya pembinaan hubungan baik antar-manusia yang telah berlangsung maupun yang akan datang.

Alternatif penyelesaian sengketa mempunyai kecocokan dengan budayatradisional Indonesia karena dengan musyawarah mufakat. Terdapat beberapakeuntungan yang ada dalam APS ini antara lain :

1. Alternatif penyelesaian sengketa dilakukan dengan cara yang cepat karenadalam prosedur APS ini dilakukan dengan cara informal.

2. Keputusan yang diperoleh berasal dari kesepakatan para pihak, dimanapara pihak mempunya kesempatan menuangkan hal-hal apa saja yangmereka inginkan tanpa campur tangan pihak ketiga. Pihak ketiga hanyaberusaha untuk menyatukan persepsi atau pendapat antara mereka yangbersengketa.

3. Alternatif penyelesaian sengketa dilakukan dengan cara rahasia sehinggasegala hak-hak mereka dapat terlindungi.

4. Keputusan yang dihasilkan mempunyai kekuatan hukum yang mengikatpara pihak dimana keputusan itu sama dengan keputusan pengadilan yangtelah berkekuatan hukum tetap.

5. Hubungan yang baik antara para pihak jika proses APS ini berhasil makakan tetap menjamin hubungan antara para pihak yang bersengketa agartetap baik.

Alternatif penyelesaian sengketa (termasuk arbitrase) dapat diberi batasansebagai kumpulan prosedur atau mekanisme yang berfungsi memberi alternatifatau pilihan suatu tata cara penyelesaian sengketa melalui bentuk aps/arbitraseagar memperoleh putusan akhir dan mengikat para pihak.

Pembahasan ini lebih dititikberatkanpada penyelesaiansengketa diluar (Peradilan Umum),yang secara garis besardibedakan atas 2 yakni pertama:Penyelesaian sengketa secara arbitrase;dan Kedua, penyelesaian sengketa secara alternatif penyelesaian sengketa, yangmasing-masing dibahas lebih lanjut sebagaiberikut: a) Arbitrase b) Konsultasi c) Negosiasi d) Mediasi e) Konsiliasi f) Penilaian Ahli.

Sengketa yang ada di Masjid Tawakkal kalau peneliti analisis dari unsur kepentingan maka kedua belah pihak sama-sama mempunyai kepentingan yang berbeda, sehingga terjadilah konflik antara keduanya. Akan tetapi kalau Konflik ini kita analisis menurut teori penyelesaian konflik (conflict resolution theory), dapat dijelaskan sebagai berikut:

a) Masalah resources (sumber-sumber seperti:tanah, dana atau uang, perumahan);

Dari hasil penelitian dilapangan maka penulis dapat menyimpulkan 
bahwa terjadinya konflik di Masjid Tawakkkal adalah konflik yang berupa status tanah yang diserahkan oleh wakif kepada nadzir.

b) Masalah interests atau needs (kepentinganatau kebutuhan yang berbeda); Dalam masalah kepentingan di Masjid Tawakkal banyak unsur Kepentingan yang berbeda-beda sehingga menimbulkan konflik yang tidak pernah selesai.

c) Masalahvalues (nilai-nilai agama, budaya, moral);

Dari nilai agama peneliti dilapangan kebanyakan masyarkat tempat Masjid berdiri adalah kaun Nahdatul Ulama' sedangkan wakif berkeinginan ingin memberika wakaf tersebut kepada Muhammadiyah khususnya yang bergerak di bidang pendidikan lebih tepatnya adalah lembaga dakwah yang berbasis pemdidikan sesuai dengan wasiat $\mathrm{Al}$ marhum H Ghozali.

d) Masalah information (kurangnya informasi, adanya misinformasi, perbedaan interpretasi data);

Dari kurangnya informasi tentang status tanah Masjid Tawakkal yang merupakan hak milik atas nama ahli waris yang bernama Ahmad Aswin yang beredar di masyarakat sekitar yang menggiring agar diwakafkan ke pada Nahdatul Ulama' dan kurangnya pengertian dari masyarakat sekitar bahwa dalam memberikan wakaf itu tidak bisa di interfensi dari pihak manapun. Hal ini berbeda yang terjadi Masjid Tawakkal yang di dalamnya banyak interfensi kepentingan di dalamnya sehingga terjadi simpang siur informasi yang terjadi sehingga masyarakat dalam hal menafsirkan sendiri-sendiri sehingga akan lebih memperuncing permasalahan wakaf tersebut.

e) Masalah relationships (hubungan individu atau pribadi);

Hubungan antara nadzir yang diberikan amanah oleh wakif pertama kali adalah $\mathrm{H}$ Masrur sampai sebelum meninggal, amanah tersebut diberikan kembali kepada wakif. Ada ketidaksingkronan antara pengurus yang baru sejak meninggalnya $\mathrm{H}$ Masrur yasir dengan wakif sehingga mereka berpegangan pada prinsip masing-masing sampai di mediasi berkali kali akan tetapi tidak ada hasil yang dapat menyelesaikan masalah tersebut.

f) Masalah structures (struktur kekuasaan, ketidakseimbangan kekuasaan). ${ }^{7}$ Berbicara tentang kekuasaan yang terjadi di Masjid Tawakkal adalah pemegang kekuasaan sekarang ini bukanlah nadzir yang diserahkan kepada wakif akan tetapi pengurus yang baru dan membentuk kenadiran yang baru tanpa adanya landasan ikrar wakafnya.

${ }^{7}$ Sarjita, Teknik dan Strategi PenyelesaianSengketa Pertanahan, (Yogyakarta: TugujogjaPustaka, 2005), hal. 19. 
Dari penjelasan tersebut di atas faktor terjadinya konflik dan peyelesain konflik di luar pengadilan menurut Undang-undang Republik Indonesia Nomor 30 Tahun1999 tentang Arbitrase dan Alternatif Penyelesaian Sengketa (Pasal 1 angka 10) dan Pasal 1 PERMA No. 1 Tahun 2016 tentang Prosedur Mediasi di Pengadilan.

Dengan demikian penyelesain sengketa Masjid Tawakkal mulai dari masalah sumber tanah atau setatus tanah wakaf, masalah kepentingan, kultur Agama, dan hubungan pengurus dengan wakif dan pembagian kekuasaan yang di temuai dilapangan semua unsur tersebut ada dan bisa di analisis penyelesainnya dengan peyelesain di luar pengadilan dengan mediasi.

\section{Peranan Badan Wakaf Indonesia (BWI) Dalam Menyelesaikan Sengketa Di Masjid Tawakkal}

Pengertian peranan menurut kamus besar Bahasa Indonesia mempunyai arti sebagai berikut: peranan adalah tindakan yang dilakukan seseorang atau sekelompok orang dalam suatu peristiwa atau bagian yang dimainkan seseorang dalam suatu peristiwa. ${ }^{8}$

Peranan badan wakaf terdapat dalam pasal 47 ayat (1) menyebutkan, bahwa dalam rangka memajukan dan mengembangkan perwakafan nasional dibentuk Bandan Wakaf Indonesia. Adapun dalam Pasal 48 dalam Undangundang yang sama disebutkan juga bahwa Badan Wakaf Indonesia berkedudukan di Ibukota Negara Kesatuan Republik Indonesia dan dapat membentuk perwakilan di Propinsi dan/atau Kabupaten/Kota sesuai dengan kebutuhan. Namun demikian pembentukan perwakilan Badan Wakaf Indonesia di daerah dilakukan setelah Badan Wakaf Indonesia berkonsultasi dengan pemerintah daerah setempat.

Adapun tugas dan wewenang Badan Wakaf Indonesia ini menurut menurut Pasal 49 ayat (1) adalah: melakukan pembinaan terhadap nadzir dalam mengelola dan mengembangkan harta wakaf; melakukan pengelolaan dan pengembangan harta benda wakaf berskala nasional dan internasional, memberikan persetujuan dan/atau izin atas perubahan peruntukan dan status harta benda wakaf; memberhentikan dan mengganti nadzir, memberikan persetujuan atas penukaran harta benda wakaf, memberikan saran dan pertimbangan kepada Pemerintah dalam penyusunan kebijakan di bidang perwakafan.

Sedangkan pada ayat (2) Pasal yang sama dinyatakan bahwa dalam melaksanakan tugas sebagaimana dimaksud pada ayat (1) Badan Wakaf

${ }^{8}$ Kamus besar Bahasa Indonesia, 2008:1173. 
Indonesia dapat bekerjasama dengan instansi Pemerintah baik Pusat maupun Daerah, organisasi masyarakat, para ahli, badan internasional, dan pihak lain yang dipandang perlu.

Dari Pasal di atas jelas bahwa tugas utama Badan Wakaf Indonesia adalah membina para nadzir wakaf yang ada di Indonesia dengan melakukan berbagai upaya seperti pelatihan, advokasi, membuat percontohan dan lain-lain yang dapat menggairahkan nadzir dalam mengelola wakaf. Di samping itu Badan Wakaf iuga bertugas membantu nadzir wakaf yang mempunyai kesulitan dalam mengelola wakaf.

BWI sebagai lembaga wakaf yang bersifat nasional selain bertugas mengkoordinasikan para nadzir, sebaiknya juga memprakarsai kerja sama antar nadzir, dengan demikian mereka dapat saling tolong menolong dalam pengelolaan wakaf.

Persoalan yang dihadapi nadzir di Indonesia sebenarnya bukan hanya mengenai cara pengelolaan, akan tetapi juga menyangkut masalah dana yang diperlukan untuk mengembangkan benda wakaf, sengketa tanah wakaf dan lain-lain. Dalam masalah dana, sebaiknya BWI mengarahkan nadzir untuk mendapatkan dana pemeliharaan harta wakaf, sedangkan terhadap tanah wakaf yang bermasalah, BWI harus membantu menyelesaikannya.

Diharapkan dengan adanya BWI berbagai persoalan wakaf dapat teratasi. Di samping itu, BWI juga diharapkan dapat melakukan advokasi dan mengurus benda wakaf yang telantar, serta membantu pemerintah dalam bidang kebijakan regulasi wakaf. Dilihat dari tugas dan fungsinya, BWI mempunyai tanggung jawab yang cukup berat untuk memberdayakan wakaf di Indonesia.

Badan wakaf Lowokwaru menyatakan bahwa penyelesaian sengketa wakaf BWI menggunakan metode musyawarah untuk mencapai mufakat dalam menyelesaikan sengketa hal ini di amanatkan oleh Undang-undang nomer 41 tahun 2004 tentang wakaf pasal 62 ayat 1 dan 2 .

Hal ini senada apa yang dilakukan oleh BWI dalam menyelesaikan kasus Masjid Tawakkal yang belum ada ujungnya. Hal ini pernah dilakukan pihak BWI yang diprakarsai oleh Lurah Tulusrejo Bapak Batin Adimolyo yaitu mempertemukan antara pengurus Masjid Tawakkal yang di wakili oleh H Imron dan tokoh masyarakat dengan ahli waris wakif yang di wakili oleh Ahmad Janu Permadi dengan dihadiri oleh BWI Kota Malang, dalam pertemuan tersebut di bahas masalah ikrar wakaf yang mana BWI memediasi antara keduanya agar Wakaf ini (Masjid Tawakkal) tersebut, dilkrarkan dan dibuatkan akta ikrar wakafnya. BWI memberi pengarahan agar Ikrar Wakaf tersebut melalui KUA Lowokwaru agar Masjid Tawakkal kebelakangnya tidak akan terjadi perselisian lagi, akan tetapi dari 
musyawarah tersebut dari pihak keluarga ahli waris tetap pada semula akan tetap menjalankan wasiat Almarhum $\mathrm{H}$ Asnan Ghozali yang ingin wakaf tersebut jatuh pada lembaga pendidikan. Meskipun BWI telah membuat nadzir baru serta membuat surat permohonan pemecahan sertifikat akan tetapi dari pihak ahli waris sertifikat tersebut tidak akan dikasihkan dan keluarga belum memutuskan mau dijatuhkan kemana wakaf tersebut mau kemuahammadiyah apa ke Nahdatul Ulama' yang pada akhirnya pihak keluarga $\mathrm{H}$ Ghozali membiarkan kepengurusan sekarang secara fisik sedangkan ahliwaris menguasai secara autentik.

Penyelesaian sengketa kalau kita analisis dari teori kepastian hukum maka kedudukan masjid secara hukum belum mempunyai kekuatan hukum, karena belum adanya akta ikrar wakaf yang didaftarkan ke badan pembuat akta ikrar wakaf sehingga status masjid masih status hak milik.

Kalau kita analisis dari teori Undang-undang terutama yang berkenaan dengan wakaf maka dapat kita analisis dari pasal 62 ayat (1) yang sudah dilakukan yaitu dengan musyawarah akan tetapi tidak ada hasilnya. Sehingga permasalahan wakaf tersebut tidak ada hasilnya. Dalam kasus Masjid Tawakkal kalau BWI menjalankan amanat Pasal 62 ayat 1 Undang-Undang Wakaf tersebut maka hanya menjalankan mediasi yang tidak ada ujungnya. Sehingga BWI dalam hal ini harus mendorong kedua belah pihak yang bersengketa membawa kasus tersebut ke pengadilan Agama setempat, sehingga dapat di mediasi di pengadilan sesuai dengan amanat Pasal 1 PERMA No. 1 Tahun 2016 tentang Prosedur Mediasi di Pengadilan yaitu: mediasi adalah cara penyelesaian sengketa melalui proses perundinganuntuk memperoleh kesepakatan para pihak dengan dibantu oleh mediator. Mediator adalah hakim atau pihak lain yang memiliki sertifikat mediatorsebagai pihak netral yang membantu para pihak dalam proses perundinganguna mencari berbagai kemungkinan penyelesaian sengketa tanpamenggunakan cara memutus atau memaksakan sebuah penyelesaian.

Dengan kata lain mediasi dilakukan di dalam pengadilan antara kedua belah pihak yang saling bersengketa agar mendapatkan jalan yang disepakati bersama. Akan tetapi kalau kita analisis dari Pasal 62 ayat (1) tidak mencapai kata mufakat maka BWI sebagai mediator mendorong keduanya untuk menyelesaikan sengketa melalui pengadilan sesuai dengan amanat Pasal 62 ayat (2) Undang-undang Nomor 41 tahun 2004 yaitu penyelesain masalah melalui jalur pengadilan. Oleh sebab itu penulis memberikan solusi dalam kasus sengketa Masjid Tawakkal di kelurahan Tulusrejo Kecamatan Lowokwaru Kota Malang kalau ingin menyelesaikan sengketa yang tidak ada ujungnya, maka saran saya adalah dibawa ke meja hijau atau dibawa kasus tersebut ke Pengadilan Agama Kota Malang. 


\section{PENUTUP}

Faktor-Faktor terjadinya sengketa antara nadzir tanah wakaf dengan ahli waris wakif di Masjid Tawakkal. Sumber dari peyebanya sengketa tanah wakaf di Masjid Tawakkal adalah belum adanya ikrar wakaf secara autentik yang di-syahkan oleh pembuat akta ikrar wakaf sehingga ahli waris masih merasa memiliki tanah dan bangunannya tersebut dan ahli waris ingin memiliki fisik dan kepemilikan secara hukum.

Bentuk-bentuk penyelesaian masalah jika terjadi sengketa antara nadzir tanah wakaf dengan ahli waris wakif. Dalam penyelesain sengketa di Masjid Tawakkal menggunakan metode penyelesaian sengketa di luar pengadilan sesuai dengan amanat Undang-undang Nomor 41 tahun 2004 tentag Wakaf Pasal 62 ayat (1) yaitu dengan cara musyawarah mufakat atau kata lain dengan mediasi.

Peranan Badan Wakaf Indonesia (BWI) dalam menyelesaikan sengketa di Masjid Tawakkal. Arti peranan dalam penyelesain sengketa tanah wakaf di masjid tawakkal adalah suatu tindakan yang dilakukan oleh seseorang atau kelompok dalam suatu peristiwa sengketa. Peranan BWI dalam menyelesaikan sengketa di Masjid tawakkal adalah menggunakan mediasi sesuai dengan amanat Undang-undang Nomor 41 Tahun 2004 Tentang Wakaf pasal 62 ayat 1 yaitu dengan mediasi atau musyawarah mufakat antara kedua belah pihak, akan tetapi jika hal ini tidak berhasil maka menggunakan ayat 2 yaitu dengan cara mengajukan ke pengadilan sehingga ada solusi dalam penyelesain sengketa yang sudah berlarut-larut.

Solusi hukum yang diberikan penulis dalam penyelesaian sengketa tanah wakaf ini adalah mengajukan gugatan sengketa ke pengadilan Agama guna mendapatkan pemecahan dalam permasalahan tersebut dan mendapatkan kepastian hukum dari status masjid yang berdiri atas lahan dengan status hak milik, sehingga ujung dari permasalahan akan selesai dengan status wakaf dan dapat dinikmati oleh masyarakat muslim seluruh dunia.

\section{KESIMPULAN}

\section{Buku}

Frans Hendra Winarta, 2011, Hukum Penyelesaian Sengketa Arbitrase Nasional Indonesia Dan Internasional, Jakarta: Sinar Grafika.

Henry Campbell Black,1989, Black's Law Dictionary, West Publishing Co. St. Paul

Kamus besar Bahasa Indonesia 2008.

Sayid Sabiq, 1983, Fiqh al Sunnah, Jilid 3.Beirut: Dar al Fikr. 
Sukandarrumidi, 2006, Metodologi Penelitian: Petunjuk Praktis untuk Peneliti Pemula, Yogyakarta: Gajah Mada University Press.

Soerjono Soekanto, 1986, Pengantar Penelitian Hukum, Jakarta: Universitas Indonesia Press.

Sarjita,2005, Teknik dan Strategi PenyelesaianSengketa Pertanahan, Yogyakarta: Tugujogja Pustaka.

\section{Peraturan perundang-undangan}

Undang-undang Nomor 41 Tahun 2004 tentang Wakaf.

Undang-undang Republik Indonesia Nomor 30 Tahun1999 tentang Arbitrase dan Alternatif penyelesaian sengketa.

PERMA No. 1 Tahun 2016 tentang Prosedur Mediasi Di Pengadilan.

\section{Internet}

Nisayustia1. Blogspot.com Di Unduh Pada Hari Senin Tanggal 25 Februari 2019 pukul 01,00 Wib. 